
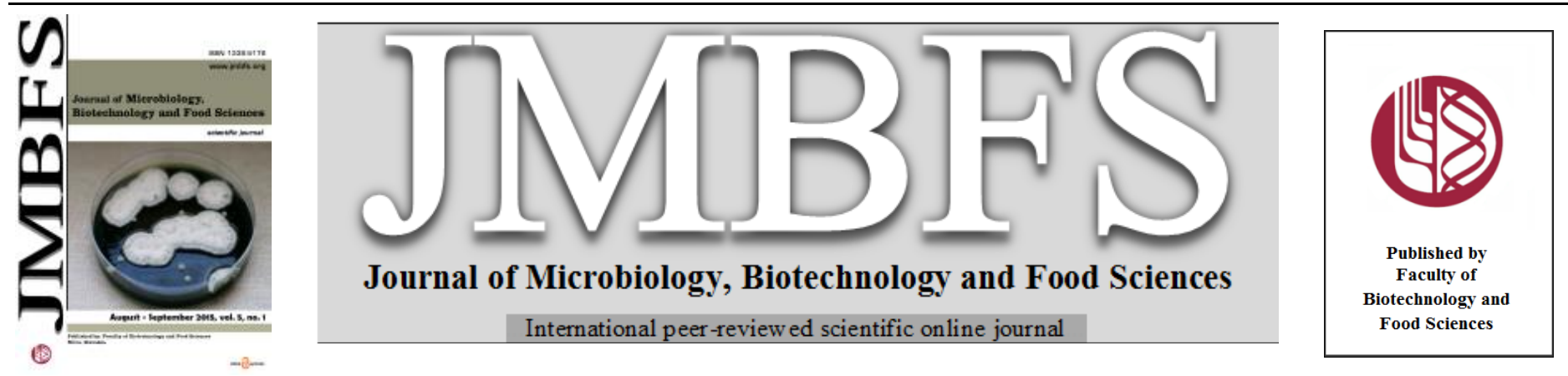

\title{
THE EFFECT OF FIBRE FROM VARIOUS ORIGINS ON THE PROPERTIES OF DOUGH AND BAKERY PRODUCTS
}

\author{
Eva Ivanišová* ${ }^{I}$, Marián Tokár ${ }^{I}$, Tatiana Bojňanská ${ }^{1}$
}

Address(es): Ing. Eva Ivanišová, $\mathrm{PhD}$.,

${ }^{1}$ Department of Storage and Processing Plant Products, Slovak University of Agriculture, Faculty of Biotechnology and Food Sciences, Tr. A. Hlinku 2, 94976 Nitra, Slovak Republic.

*Corresponding author: eva.ivanisova@uniag.sk

doi: 10.15414/jmbfs.2015.5.1.73-80

\section{ARTICLE INFO}

Received 19. 5. 2015

Revised 9. 6. 2015

Accepted 25. 6. 2015

Published 1. 8. 2015

Regular article OPEN $\partial_{\text {ACCESS }}$

\begin{abstract}
Wheat bread is a major component of people's diet all over the world. There has been increasing demand for food products with additional health benefits. Fibre is an important component of diet and nutrition and is one of the groups of biologically important substances consumed in insufficient quantity. In this respect, the enrichment of bread with the functional fibre is interest for the consumer as well as the cereal industry. Different materials can serve as a source of fibre for bread, either directly indu strially prepared (inulin, potato fiber) or natural materials with a high content of fibre. The aim of this work was to monitor changes in quality parameters of flour, dough and bread depending on the type and amount of addition.

Mixes of wheat flour and additives were prepared by substitution of wheat flour by 5, 10, 15, 20 and $25 \%$ of inulin; 1, 3, 5 and $7 \%$ of potato fiber; 5, 10, 15, 20 and 25\% of malt; 10, 20, 30, 40 and 50\% of naked barley. For the evaluation of dough Farinograph was used; bread quality was evaluated 24 hours after baking (volume, specific loaf volume, volume efficiency, cambering etc.). The sensory evaluation was conducted according to sensory descriptor. The addition of fibre as nutritionally important component is justified by the positive impact on the health of consumers. However non-bakery crops contain elements which might negatively influence the technological properties. Based on the results obtained by observing the rheological properties of the tested doughs, it can be stated that the use of additives worsened the physical properties of doughs and the technological and organoleptic quality of final products. The composite flours had longer dough development time and dough stability, whereas the degree of dough softening decreased caused by destruction and shortening of gluten. Dough showed worse workability and the decrease of the water absorption which is undesirable from an economic point of view since it increases the amount of flour needed to produce bread of the same weight. The loaves prepared with an addition were evaluated to be of a lesser quality from the technological point of view in comparison with pure wheat loaves. The additions reduced the volume of bread except for barley which in addition up to $30 \%$ has increased the bread volume in comparison to control loaves. Based on comprehensive evaluation (including organoleptic) maximum acceptable additions can be recommended as follows: inulin up to $5 \%$, potato fiber up to $7 \%$, malt up to $10 \%$ and naked barley up to $30 \%$. Fiber content bread with the recommended added amount was $5.13 \%$ for inulin, $7.80 \%$ for potato fiber, $4.98 \%$ for matl and $6.75 \%$ for naked barley.
\end{abstract}

Keywords: bread, dough, inulin, malt, Potex, barley, rheology, organoleptic quality

\section{INTRODUCTION}

Fibre is an important component of diet and nutrition. Generally speaking, dietary fibre is the edible parts of plants, or similar carbohydrates, that are resistant to digestion and absorption in the small intestine (Lattimer and Haub, 2010). Dietary fibre is composed of total dietary fibre (TDF), which includes both soluble (SDF) and insoluble dietary fibres (IDF). The importance of the dietary fibre is increasing due to its beneficial effects on the reduction of cholesterol levels and the risk of colon cancer. Recently, innovative food products promoted with health benefits are increasingly becoming popular. "Functional Foods" is an interesting research area in processed food industry. Several professional and international health organizations have defined functional foods as a functional food is a food given an additional function by adding new ingredients or more of existing ingredients that provide beneficial physiological or health. High fiber bread is one of the known products categorized in 'Functional food' which is health beneficial. White bread has more popular because of its organoleptic properties (Ingram and Shapter, 2006), however, there are increasing demands toward consumption of high fibre breads due to their health prompting properties. Bread has always been one of the most popular and appealing food products due to its superior nutritional, sensorial and textural characteristics. Bakery products, particularly bread, take a significant share in the food guide pyramid for daily food choices (Sangnark et al.; 2004Goesaert et al., 2005) and therefore can be a convenient food for adjusting the daily food intake according to specific needs. Dietary fibres in bread are a versatile functional food ingredients giving many benefits to human health
(Ribotta et al., 2003; Angioloni et al., 2009) and playing a very important role in the human diet, helping in solving some digestive problems and also positively contributing to a long list of non infectious diseases (Topping, 1991; Sangnark et al., 2004).

Inulin is used increasingly for obtaining new foods as bread, bakery products, milk, cereal snacks and beverages due to various reasons: it is a soluble fibre with health benefits as prebiotic, it has low caloric value, it can be used as a substitute for sugar or fat, it is appropriate because diabetics use low GI. Inulin promotes high absorption of minerals, especially calcium (Kim et al., 2004) and magnesium; the increase in bone mineral density, reduces the quantities of lymph lipids (e.g. cholesterol and triglycerides) favouring a good heart activity. Barley is now gaining renewed interest as a functional food ingredient because it is considered as a rich source of fibre, mainly $\beta$-glucans (Soares $\boldsymbol{e t}$ al., 2007) Barley $\beta$-glucan is effective in flattening the postprandial blood glucose (Ostman et $\boldsymbol{a l}$., 2006) and reducing the cardiovascular disease risk factors in comparison with other sources of soluble fibers (Behall et al., 2004).

Potato peel, a by-product from the potato industry, has been reported to be a very rich (higher than wheat bran) and good source of fibre with high water-holding capacity (Camire et al., 1997).

Except to supposed increase the nutritional value of bakery products with added fiber (inulin, potato fiber) and raw materials containing fiber (naked barley, malt) is necessary to think of their technological quality and rheological properties of dough. Measuring the rheological properties of dough intended for bread production is relatively complicated, connected with exploitation of specific equipment. Rheology studies relations between tension which the material is 
exposed to, final dimension of material deformation and time. It is very important to understand the rheological behaviour of bread dough as well as mechanical properties of the dough and control finished products (Př́ihoda et al., 2003, Mirsaeedghazi et al., 2008).

The objectives of this study were to formulate and develop functional breads from wheat flour composited with inulin, potato fiber, naked barley, malt and to evaluate the products baking properties, nutritional, sensory quality and consumer overall acceptability.

\section{MATERIAL AND METHODS}

\section{Material}

Wheat flour type T-650 as basic material was obtained from the operating grinding mill (Vitaflóra Kolárovo, Slovak Republic). To this flour were added selected polysaccharides and cereals containing polysaccharides potentially suitable for enrichment bakery products in the quantities: $5 \%, 10 \%, 15 \%, 20 \%$ and $25 \%$ of the commercial manufactured inulin (Deracel CF 20) from chicory (Dera Food Technology, Belgium); 10\%, 20\%, 30\%, $40 \%$ and 50\% of the milling naked barley (Hordeum vulgare subsp. nudum L.), variety PRBL-4 (The Central Controlling and Testing Institute in Agriculture Spišská Belá, Slovak Republic); $5 \%, 10 \%, 15 \%, 20 \%$ and $25 \%$ of the milling malt, variety Levan (Hordeum Sládkovičovo, Slovak Republic); 3\%, 5\%, 7\% and 10\% of potato fibre POTEX, (Lyckeby Culinar, Horaždovice, Czech Republic). Commercial compressed yeast was used for the bread making.

\section{Method}

\section{Chemical Analysis}

Dry matter, starch, ash, protein and acidity were determined by the following standard AACC method 08-01. Nitrogen content was measured by the semi micro-Kjeldahl method. Nitrogen was converted to protein by using a factor of 5.7. Sedimentation index (Zeleny test) and falling number were determined by ICC method No 116/1 and ICC method No 107/1. Wet gluten, extensibility and swelling of gluten were determined by STN 461011-9. Soluble, insoluble and total dietary fibre content was determined according to the AACC method 3221.01 and 32-06.01.

\section{Baking Tests}

A straight dough bread making process was performed. Basic dough formula on $100 \mathrm{~g}$ flour basis consisted of salt (1.8 g), compressed yeast $(4 \mathrm{~g})$, saccharose (1 $\mathrm{g})$ and the amount of water required to reach $500 \mathrm{BU}$ of consistency. The doughs were optimally mixed, divided and hand moulded. Dough was proofed at $30^{\circ} \mathrm{C}$ and relative humidity $85 \%$ for 35 min up to optimum volume increase and baked first at $240^{\circ} \mathrm{C}$ for $10 \mathrm{~min}$. and after at $220^{\circ} \mathrm{C}$ for $25 \mathrm{~min}$. The bread quality attributes were evaluated after cooling for $24 \mathrm{~h}$ at room temperature.

\section{Dough Characteristics}

The effect of the different level of inulin, potato fiber, naked barley and malt on dough rheology during mixing was determined by a Farinograph (Brabender, Duisburg, Germany), following the ICC method No 115/1. The parameters determined were water absorption or percentage of water required to yield dough consistency of $500 \mathrm{BU}$ (Brabender Units), dough development time (time to reach maximum consistency in minutes), stability (time dough consistency remains at $500 \mathrm{BU}$ ), degree of softening (consistency difference between height at peak and that $10 \mathrm{~min}$ later, $\mathrm{BU})$.

\section{Bread Quality Evaluation}

Bread quality parameters included volume (determined by seed displacement in a loaf volume meter), specific volume, loss during baking, bread yield, cambering and volume yield were evaluated.
Sensory evaluation (ISO 6658) of the bread samples were carried out by 15 panelists. They evaluated each product for quality attributes: crumb, color, smoothness, aroma, flavor chewiness, crust color and hardness. Overall acceptability of each quality attribute was rated with a score of 0 (lowest) to 5 (highest). Overall acceptability to each bread was also evaluated by 9 point hedonic scale (1 - lowest; 9 - highest)

\section{RESULTS AND DISCUSSION}

\section{Results of Flour Tests}

The results obtained from the chemical analysis are shown in Table 1,2 and 3 . The increased supplementation of wheat flour with inulin, naked barley, malt and potato fiber greatly affected the physico-chemical quality of composite bread. The proximate values for ash and fiber content were lowest in control sample (100\% wheat flour T-650), which served as control. The proximate values increased with increasing levels of substitutions except for starch content which showed the reverse. The starch content was highest in control sample (in each variant) and lowest in sample with $25 \%$ of inulin $(48.18 \%)$. Similar trends (lowest carbohydrates and food energy value) were reported by Serem $\boldsymbol{e t}$ al (2011) in the fortification of wheat flours with defatted and non-defatted soy flour, respectively.

The content of wet gluten in control flour was very high and reached from 32.8 to $36.2 \%$. Wet gluten is a cohesive visco-elastic proteinaceous substance obtained after washing out the starch granules from dough. Quality gluten, described by the degrees of strength and extensibility, allows a sufficient expansion, good distribution and retention of the gas cells within fermenting dough (Grobelnik Mlakar et al., 2009). The substitution of wheat flour with inulin, malt, naked barley and potato fiber lower its content in composite flours. With increasing share of addition of flour decreased the extensibility of gluten, from $13 \mathrm{~cm}$ in control flour to $10 \mathrm{~cm}$ in composite flour with $50 \%$ of malt and $1 \%$ of potato fiber. Determination of the gluten swelling is based on hydrophilic character of gluten.

During hydration gluten swells according to protein content. Weak gluten swells too quickly and after that melt. Swelling of gluten was influenced by the content of inulin, malt, naked barley and potato fiber in composite flour, similarly as in wet gluten, increasing share of addition lowered and worsen the gluten swelling The gluten strength was expressed through the sedimentation volume (index) Substitution of wheat flour with inulin, malt, naked barley and potato fiber lowered the sedimentation index. The worst was $50 \%$ share of naked barley, which decreased this parameter under the requirements of standard wheat flour according norm STN 461011-9.

Falling number is method to estimate $\alpha$-amylase activity of flour.. Generally, a falling number value of 350 seconds or longer indicates a low enzyme activity and very sound wheat quality. As the amount of enzyme activity increases, the falling number decreases. Values below 200 seconds indicate high levels of enzyme activity (Perten, 1964). Addition of flour with malt had very intensive effect on enzyme activity, which indicated worse bread crumb quality - sticky bread crumb and low volume. The similar effect was signed also in additon with $25 \%$ of inulin. The addition of naked barley and potato fiber had positive effect to falling number; improve quality of whaet flour to optimum value, which is from 220-250.

The fibre content of the composite flours showed a percentage increase with addition of flour with inulin, malt, naked barley and potato fiber. The increased fibre and the lower starch content of addition flours have several health benefits, as it will aid in the digestion of the bread in the colon and reduce constipation often associated with bread produced from refined wheat flour (Elleuch $\boldsymbol{e t}$ al. 2011). According to well documented studies, it is now accepted that dietary fibre plays a significant role in the prevention of several diseases such as cardiovascular diseases, diverticulosis, constipation, irritable colon, cancer and diabetes (Slavin, 2005; Elleuch et al., 2011). The fibre contents of the composite flours, was within the recommended range of not more than $6 \mathrm{~g}$ dietary fibre and other nonabsorbable carbohydrates per $100 \mathrm{~g}$ dry matter (FAO/WHO, 1994). 
Table 1 Qualitative parameters of flour with addition of naked barley

\begin{tabular}{|c|c|c|c|c|c|c|c|}
\hline & & Control* & $10 \%$ & $20 \%$ & $30 \%$ & $40 \%$ & $50 \%$ \\
\hline \multirow{14}{*}{ Naked barley } & Dry Matter [\%] & 88.9 & 88.38 & 88.53 & 88.80 & 88.65 & 88.66 \\
\hline & Moisture [\%] & 11.61 & 11.62 & 11.47 & 11.42 & 11.35 & 11.34 \\
\hline & Starch content [\%] & 78.48 & 77.74 & 74.82 & 74.14 & 73.17 & 72.04 \\
\hline & Ash content $[\%]$ & 0.61 & 0.69 & 0.72 & 0.83 & 0.98 & 1.09 \\
\hline & Crude Protein [\%] & 12.48 & 12.36 & 12.27 & 11.77 & 11.74 & 11.56 \\
\hline & Acidity $\left[\mathrm{mmol} \cdot \mathrm{kg}^{-1}\right]$ & 48.00 & 50.00 & 51.00 & 55.00 & 56.00 & 61.00 \\
\hline & Falling number $[\mathrm{s}]$ & 353.00 & 329 & 312.5 & 301.5 & 282.5 & 254.00 \\
\hline & Wet gluten [\%] & 32.80 & 30.5 & 29.4 & 24.8 & 22.6 & 20.30 \\
\hline & Extensibility of gluten $[\mathrm{cm}]$ & 13.00 & 12.00 & 12.00 & 11.00 & 11.00 & 10.00 \\
\hline & Swelling of gluten $\left[\mathrm{cm}^{3}\right]$ & 22.00 & 21.00 & 17.00 & 16.00 & 14.00 & 13.00 \\
\hline & Sedimentation index $\left[\mathrm{cm}^{3}\right]$ & 40.50 & 34.50 & 29.5 & 25.00 & 19.00 & 16.00 \\
\hline & Solube Fibre [\%] & 0.89 & 1.32 & 1.49 & 2.10 & 2.52 & 3.05 \\
\hline & Insolube Fibre [\%] & 2.95 & 3.46 & 3.53 & 4.65 & 5.34 & 5.28 \\
\hline & Total Dietary Fibre [\%] & 3.84 & 4.78 & 5.02 & 6.75 & 7.86 & 8.33 \\
\hline
\end{tabular}

*Control - wheat flour T-650

Table 2 Qualitative parameters of flour with addition of inulin and malt

\begin{tabular}{|c|c|c|c|c|c|c|c|}
\hline & & Control* & $5 \%$ & $10 \%$ & $15 \%$ & $20 \%$ & $25 \%$ \\
\hline \multirow{14}{*}{ Inulin } & Dry Matter [\%] & 86.85 & 87.29 & 87.57 & 87.79 & 88.18 & 88.44 \\
\hline & Moisture [\%] & 13.15 & 12.71 & 12.43 & 12.21 & 11.82 & 11.56 \\
\hline & Starch content [\%] & 82.61 & 70.12 & 69.25 & 61.4 & 53.81 & 48.18 \\
\hline & Ash content [\%] & 0.42 & 0.44 & 0.35 & 0.34 & 0.38 & 0.31 \\
\hline & Crude Protein [\%] & 11.36 & 10.81 & 10.49 & 9.57 & 8.86 & 8.34 \\
\hline & Acidity $\left[\mathrm{mmol} . \mathrm{kg}^{-1}\right]$ & 37.00 & 36.00 & 35.00 & 34.00 & 32.00 & 29.00 \\
\hline & Falling number [s] & 316.00 & 309.00 & 294.50 & 267.00 & 236.50 & 69.50 \\
\hline & Wet gluten [\%] & 35.70 & 33.80 & 30.80 & 28.50 & 26.10 & 21.50 \\
\hline & Extensibility of gluten $[\mathrm{cm}]$ & 13.00 & 12.50 & 12.00 & 12.50 & 12.50 & 11.50 \\
\hline & Swelling of gluten $\left[\mathrm{cm}^{3}\right]$ & 21.50 & 20.50 & 20.00 & 20.00 & 21.00 & 21.00 \\
\hline & Sedimentation index $\left[\mathrm{cm}^{3}\right]$ & 36.00 & 34.50 & 32.00 & 33.00 & 33.00 & 31.00 \\
\hline & Solube Fibre [\%] & 0.83 & 2.24 & 5.70 & 7.99 & 10.51 & 13.48 \\
\hline & Insolube Fibre [\%] & 3.26 & 2.89 & 2.66 & 2.41 & 2.22 & 2.14 \\
\hline & Total Dietary Fibre [\%] & 4.09 & 5.13 & 8.36 & 10.40 & 12.73 & 15.62 \\
\hline \multirow{14}{*}{ Malt } & Dry Matter [\%] & 88.33 & 88.45 & 88.5 & 88.55 & 88.73 & 88.75 \\
\hline & Moisture [\%] & 11.67 & 11.55 & 11.5 & 11.45 & 11.27 & 11.25 \\
\hline & Starch content [\%] & 76.93 & 75.74 & 77.85 & 76.31 & 75.94 & 73.99 \\
\hline & Ash content [\%] & 0.60 & 0.54 & 0.75 & 0.73 & 0.70 & 0.96 \\
\hline & Crude Protein [\%] & 13.50 & 13.20 & 13.10 & 12.80 & 13.30 & 12.90 \\
\hline & Acidity $\left[\mathrm{mmol} \cdot \mathrm{kg}^{-1}\right]$ & 34.00 & 46.00 & 53.00 & 62.00 & 72.00 & 77.00 \\
\hline & Falling number [s] & 359.00 & 63.00 & 62.00 & 62.00 & 62.00 & 62.00 \\
\hline & Wet gluten [\%] & 36,20 & 33.90 & 31.60 & 30.50 & 29.30 & 25.90 \\
\hline & Extensibility of gluten $[\mathrm{cm}]$ & 13.00 & 12.00 & 12.00 & 12.00 & 12.00 & 12.00 \\
\hline & Swelling of gluten $\left[\mathrm{cm}^{3}\right]$ & 20.00 & 17.00 & 16.00 & 15.00 & 14.00 & 13.00 \\
\hline & Sedimentation index $\left[\mathrm{cm}^{3}\right]$ & 40.00 & 41.00 & 39.00 & 35.00 & 32.00 & 27.00 \\
\hline & Solube Fibre [\%] & 0.64 & 1.14 & 1.40 & 1.56 & 1.60 & 1.64 \\
\hline & Insolube Fibre [\%] & 2.03 & 2.49 & 3.58 & 4.03 & 4.48 & 4.86 \\
\hline & Total Dietary Fibre [\%] & 2.67 & 3.63 & 4.98 & 5.59 & 6.08 & 6.50 \\
\hline
\end{tabular}

*Control - wheat flour T-650

Table 3 Qualitative parameters of flour with addition of potato fiber (Potex)

\begin{tabular}{|c|c|c|c|c|c|c|}
\hline & & Control* & $1 \%$ & $3 \%$ & $5 \%$ & $7 \%$ \\
\hline \multirow{14}{*}{ Potato fiber } & Dry Matter [\%] & 89.13 & 89.19 & 89.20 & 89.06 & 89.19 \\
\hline & Moisture [\%] & 10.87 & 10.81 & 10.80 & 10.94 & 10.81 \\
\hline & Starch content [\%] & 82.20 & 81.93 & 80.43 & 79.92 & 79.19 \\
\hline & Ash content [\%] & 0.54 & 0.62 & 0.63 & 0.70 & 0.73 \\
\hline & Crude Protein [\%] & 11.80 & 11.80 & 11.67 & 11.63 & 11.46 \\
\hline & Acidity $\left[\mathrm{mmol} \cdot \mathrm{kg}^{-1}\right]$ & 43.00 & 43.50 & 48.00 & 49.00 & 53.50 \\
\hline & Falling number $[\mathrm{s}]$ & 419.00 & 401.00 & 397.00 & 391.00 & 374.00 \\
\hline & Wet gluten [\%] & 32.54 & 32.52 & 32.51 & 31.44 & 30.27 \\
\hline & Extensibility of gluten $[\mathrm{cm}]$ & 11.00 & 10.00 & 11.00 & 11.00 & 12.00 \\
\hline & Swelling of gluten $\left[\mathrm{cm}^{3}\right]$ & 20.00 & 22.00 & 22.00 & 22.00 & 21.00 \\
\hline & Sedimentation index $\left[\mathrm{cm}^{3}\right]$ & 37.00 & 37.00 & 35.00 & 34.00 & 34.00 \\
\hline & Solube Fibre [\%] & 0.83 & 0.89 & 1.06 & 1.16 & 1.29 \\
\hline & Insolube Fibre [\%] & 2.46 & 3.05 & 4.14 & 5.34 & 6.51 \\
\hline & Total Dietary Fibre [\%] & 3.29 & 3.94 & 5.20 & 6.50 & 7.80 \\
\hline
\end{tabular}

*Control - wheat flour T-650

\section{Results of Farinograph}

The measured values of farinographic characteristics of dough with inulin are shown in Fig. 1. In the values of water absorption was observed its growth with increased addition of inulin from $58.6 \%$ (control) to $61.8 \%$ (25\% of inulin addition to flour), what represents an increase of 5.2\%. By Hager $\boldsymbol{e t}$ al. (2011), the inulin molecules form connecting zone between water and other components of the flour mixture, which encloses a large amount of water. On the other hand, the arguments of other authors point to the fact that the replacement of starch by soluble forms of oligosaccharides and inulin leads to the reduction of water 
absorption and dough consistency (Rouille et al., 2005; Karolini-Skaradzinska et al., 2007; Peressini and Sensidoni, 2009). Based on the findings of our results, we agree with the view of Hager $\boldsymbol{e t}$ al. (2011). We observed an increase of water absorption with inulin addition of $20 \%$, while the differences between samples were not statistically confirmed depending on the added amount. Other measured farinographic values as dough development time and stability, degree of softening and farinograph quality number had an informative value only in the control. Farinograms with inulin addition were nonstandard, specific and their values were distorted.

The measured values of farinographic characteristics of dough with malt are shown in Fig. 2. With increasing proportion of malt, there was observed the decrease of water absorption from $61.5 \%$ (control) to $57.6 \%$ (25\% addition of malt) which represents decrease of $3.9 \%$. This phenomenon can be considered as a negative, which reflects to the lower yield of pastry from the same amount of flour.

At values of dough development time, there was a decrease in all of the barley additions in comparison with the control $(2.3$ minute). The lowest dough development time was observed at $25 \%$ addition of malt (1.2 minutes). As Muchová, (2001) mentioned, development time of dough below 2 minutes is characteristic for weak flour. From the above results can be deduced that the addition of malt negatively influenced the dough development time. The reason could be the absence of gluten proteins and influence of amylolytic and proteolytic enzymes high activity on the main components (starch and protein) involved in the creation of optimal dough structure.

The values of the dough stability were in the range from 1.3 minute $(25 \%$ addition of malt) to 7.7 minute (control), while the sequence from the amount of malt addition to the flour was observed and the difference between values was as much as $83 \%$. It can be stated that due to the enzymes presented in the malt components are fractured (starch, proteins, polysaccharides) into smaller and simpler compounds that cannot create flexible elastic dough resistant to deformation. For this reason, a trend of rapid consistency decrease after achieving maximum in the flour mixture with the addition of malt was observed. The degree of dough softening is connected with the destruction and shortening of gluten fibres and expresses dough resistance to further mechanical stress. The measured values ranged from $64 \mathrm{FU}$ (control) to $220 \mathrm{FU}$ ( $25 \%$ addition of malt), whereas with $5 \%$ addition of malt ( $145 \mathrm{FU})$, the difference to the control was almost $56 \%$. The values of the degree softening should be as low as possible, then it is a dough with minimal consistency decrease. This dough is provided only by strong flour. In comparison with control, farinograph quality number was significantly lower in the composite flours with the malt addition

The measured values of farinographic characteristics of dough with naked barley are shown in Fig. 3. There is an evident increase of water absorption with increasing addition of naked barley in composite flours from $63.8 \%$ (control) to $68.0 \%$ (50\% addition of naked barley), which represents an increase of water absorption around $4.2 \%$. This effect may be considered as desirable from economic aspect, because water does not represent such a financial item as flour. At values of dough development time, an increase in all of the barley addition in comparison with the control was observed. The highest value of dough development time was with 50\% addition of naked barley. Due to the higher content of non-starch polysaccharides in barley and its larger elements (milling naked barley), there was a change in the structure of dough and then the slowdown of hydration and subsequent formation of compact homogeneous mass. As Skendi et al. (2010) mention, non-starch polysaccharides and $\beta$ glucans, which are components of fiber present in barley, were added to wheat flour and significantly prolonged the development time and stability of dough in comparison with wheat flour alone, which corresponds with the results of our measurements.

The values of dough stability ranged from 7.1 minute (30\% addition of naked barley) to 14.7 minute (50\% addition of naked barley), whereas the sequence depending on the amount of addition was not observed. Degree of softening is expressed as the difference between the maximum consistency and the consistency after 12 minutes (ICC). In this parameter, the values ranged from 60 $\mathrm{FU}$ (control) to $97 \mathrm{FU}$ ( $20 \%$ addition of barley to flour), what can be classified as samples of medium quality. Because of insufficient measurement range, the $10 \%$ and 50\% addition of naked barley were not commented. Farinographic numbers of quality had an informative value only in the control, due to the non-standard curves in composite flours with addition of naked barley.

The measured values of farinographic characteristics of dough with potato fiber are shown in Fig, 4. In the values of water absorption was observed it is growth with increased addition of potex from $64.3 \%$ (control) to $75.5 \%$ (7\% of potato fiber addition to flour), what represents an increase of $11.2 \%$. We can conclude that the addition of potato fiber significantly increased water absorption of composite flours. It was caused by the presence of dietary fiber components. As mentioned Camire et al. (1997), the high water absorption of potato fibre is caused by the presence of higher concentration of cellulose, hemicellulose and lignin. Height of potato fiber addition had the greatest impact on the water absorption of flour in comparison with others addition. The potato fibers can be potentially attractive product for their unique absorption properties in food technology (Soral-Śmietana et al., 2003). At values of dough development time was observed an increased in all additions of potato fiber to the wheat flour compared to control (2.2 minutes). The largest value of dough development time was assessment with the addition of 7\%. It can be expected that due to the higher content of fiber components consisting of non-starch polysaccharides, arabinoxylan, hemicellulose, cellulose and lignin, a change in structure was occurred and thus to slow down of the hydration and to create of a compact homogeneous mass. Our findings are also confirmed by the results of the work of Kaack $\boldsymbol{e t}$ al. (2006), in which the effect of pentosan on the rheological properties of dough was examined. Pentosans which are also the components of fiber increased development time and viscosity of dough. Stability of dough is defined in minutes as the time interval from the moment when the upper edge of the curve intersects the value $500 \mathrm{FU}$ and when it leaves again. The values of stability were in the range of 9.1 minutes (control) to 18.5 minutes (3\% of the potato fiber addition), the sequence from the amount of addition to wheat flour was not observed. Based on these results it can be concluded that the addition of potato fiber above $3 \%$, significantly prolonged stability of dough. Explanation is in a slower hydration of the fiber components in the flour mixture. The values of the degree of softening were the highest in the control (58) and gradually decreased with increasing addition, while it is desirable to point out the fact that at $5 \%$ and $7 \%$ addition of potato the values were zero. It was caused by achieving of maximum dough consistency at the end of the farinograph registration and that could not be measured because of insufficient time of farinograph registration. At the values of farinograph quality number only the control and $1 \%$ addition of potato fiber had information value, whereas the curvatures of curves with higher additions of potex were untypical.
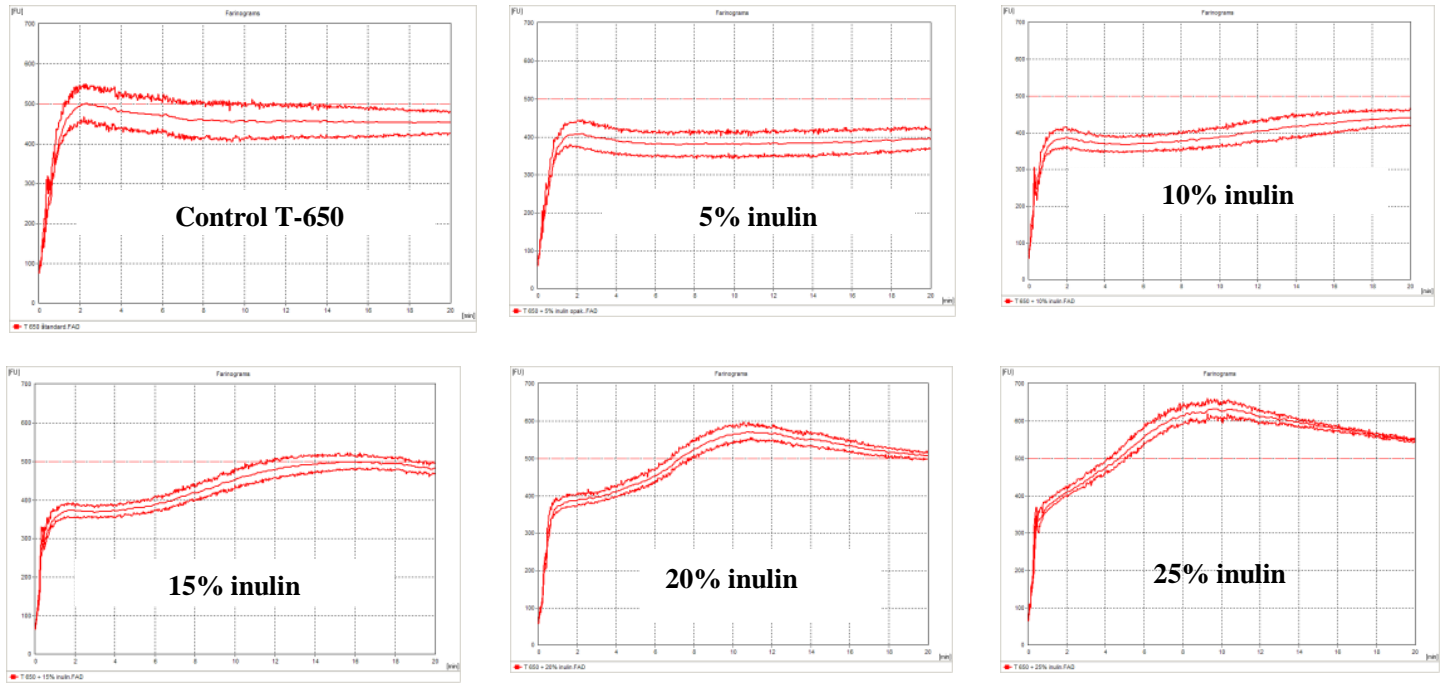

Figure 1 Farinographic characteristics of dough inulin 

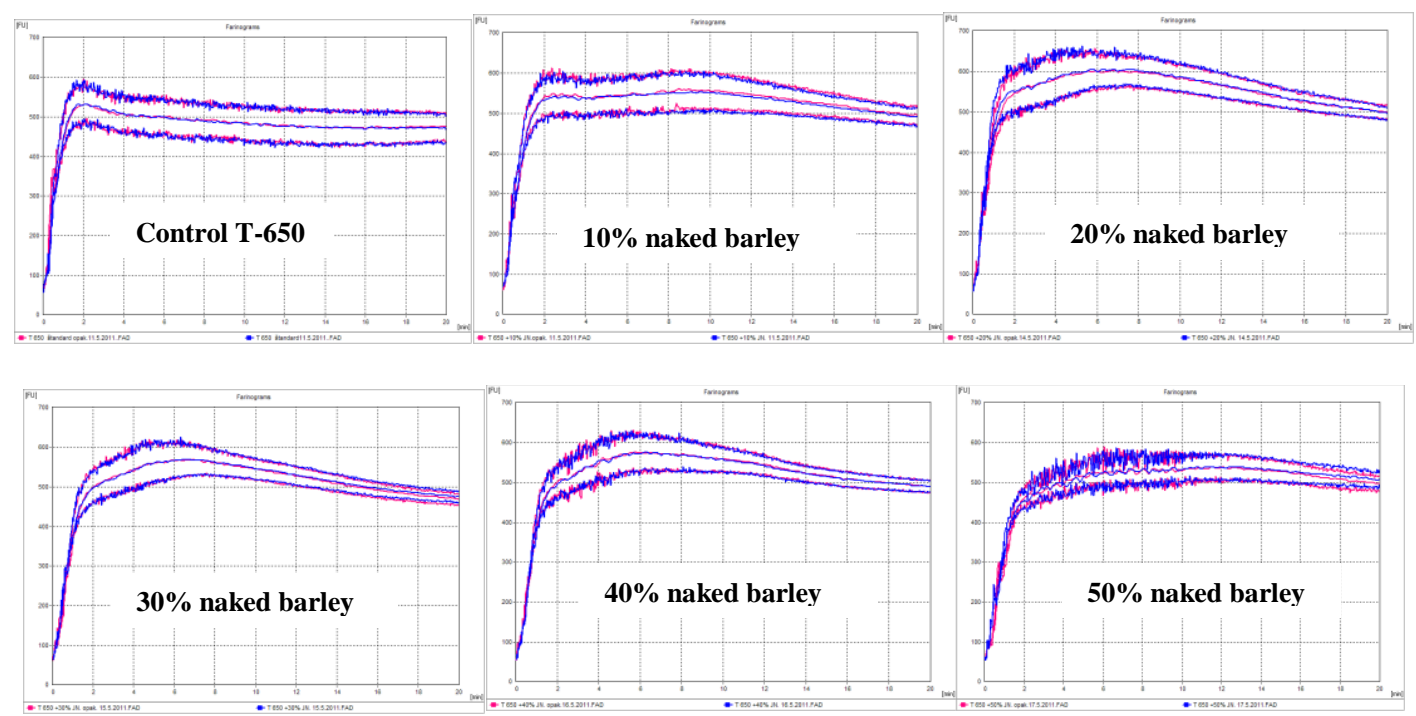

Figure 2 Farinographic characteristics of dough with naked barley
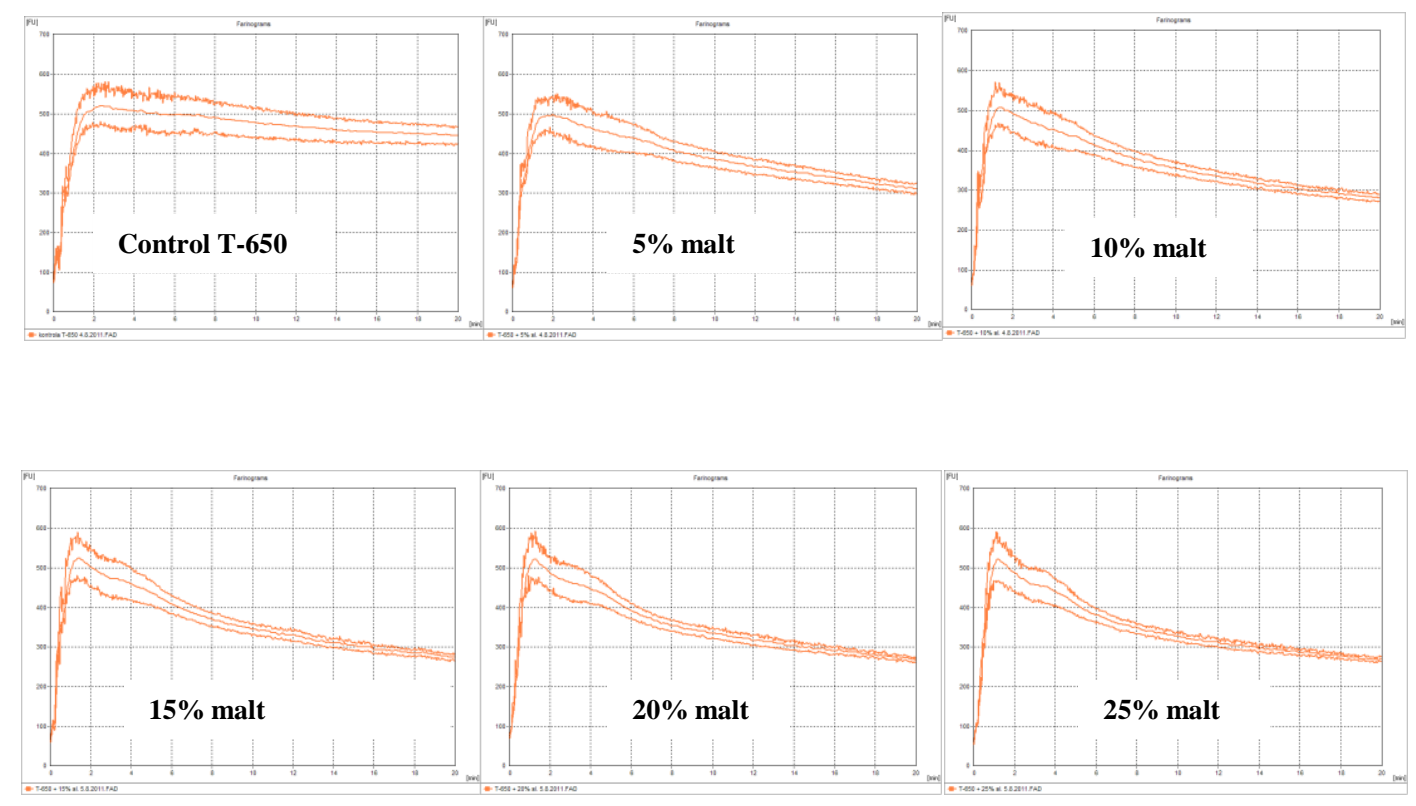

Figure 3 Farinographic characteristics of dough with malt
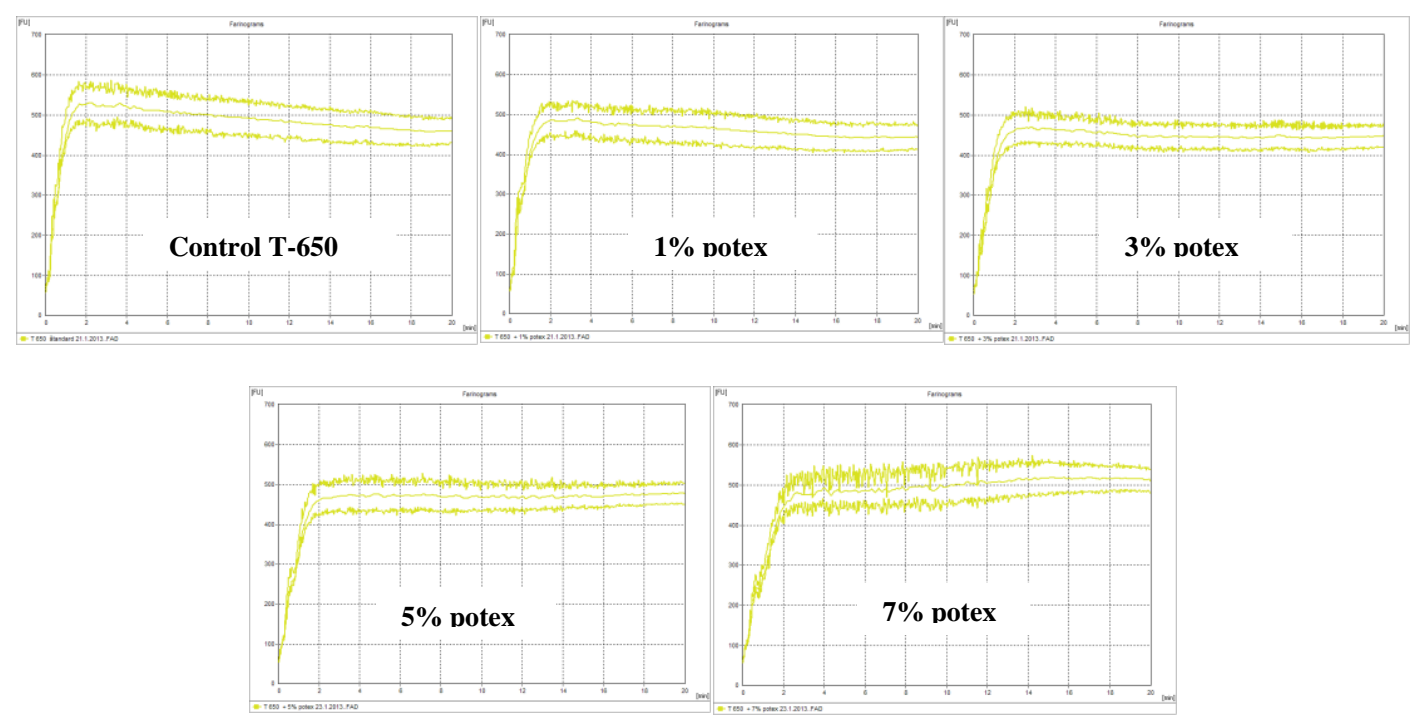

Figure 4 Farinographic characteristics of dough with potex 


\section{Results of Baking Tests}

The results of bakery experiments (Fig. 5) showed that gradually increasing proportion of inulin to flour negatively influenced on the qualitative parameters of baked bread, which resulted in a reduction in their volume, specific volume and volume yield. Reducing the volume of the bakery products with the addition of inulin referred O'Brien et al., (2003); Filipovic et al., (2008); Meyer - Peters (2009); Filipovic et al., (2010); Brasil et al., (2011) in their studies. A significant reduction in volume was evident at the addition of inulin in an amount of $5 \%$ to wheat flour what caused a difference in the amount relative to the control of up to $1075 \mathrm{~cm}^{3}$. At higher additions were more significant differences - in loaves with the addition of inulin $15 \%$ less to the volume by $40.8 \%$ compared to the control.

The results of bakery experiments showed that gradually increasing proportions of naked barley negatively impact on mostly qualitative parameters of baked bread, which resulted in a reduction in their volume, specific volume and volume yield (Fig. 5). The volume of products were reduced values with increasing addition of barley from $4000 \mathrm{~cm}^{3}$ (control) up to $2675 \mathrm{~cm}^{3}$ (addition of $50 \%$ naked barley), what representing a difference of more than $33 \%$. This effect of reducing the volume of products was expected, due to the absence gluten proteins in barley. Subsequently occurred to the weaken structure of the dough and the inability to retain a sufficient amount of gas formed in the dough. The reduction in the volume of products with the addition of barley was also found in the studies by Gill et al., (2002); Izydorczyk - Dexter (2008). It is believed that the main effect of reducing volume of the loaves lies in the absence of gluten protein in barley, and higher fiber content, mainly $\beta$-glucans, which are not able to replace gluten and create optimal viscoelastic properties.

The bread volume was in the range from $3200 \mathrm{~cm}^{3}$ (addition of malt $25 \%$ ) to $4400 \mathrm{~cm}^{3}$ (addition of malt 5\%), and the sequence was not observed in proportion to the amount of addition. The results (Fig. 5) showed interesting finding, that the bread with the addition of the malt in an amount of $5 \%$, and $10 \%$ had a higher volume than the control, while from the addition of $15 \%$ malt, there was a decreased in the volume of samples. Based on this finding, it can be assumed that the increasing bread volume with the addition of malt in an amount of $5 \%$ and $10 \%$ created a suitable baking mixes. Loaf volume is related to the value of specific volume, volume yield and cambering, where was recorded in a similar course of values.

The bread volume were reduced values with increasing addition of Potex in composite flour mixes from $4475 \mathrm{~cm}^{3}$ (control) up to $2700 \mathrm{~cm}^{3}$ (addition Potex $5 \%$ ), what representing a difference of almost $40 \%$. This effect of reducing the bread volume was partially expected, in view of the results of rheological measurements. The apparent negative effects used dietary fiber on the quality final products (bread) found, Wang et al., (2002); Sangnark - Noomhorm (2004), Sudha et al., (2007a, 2007b), which resulted in a reduction of bread volume, increasing of firmness crumb, darkening the crust and also influencing any flavor depending on the type of fiber used.

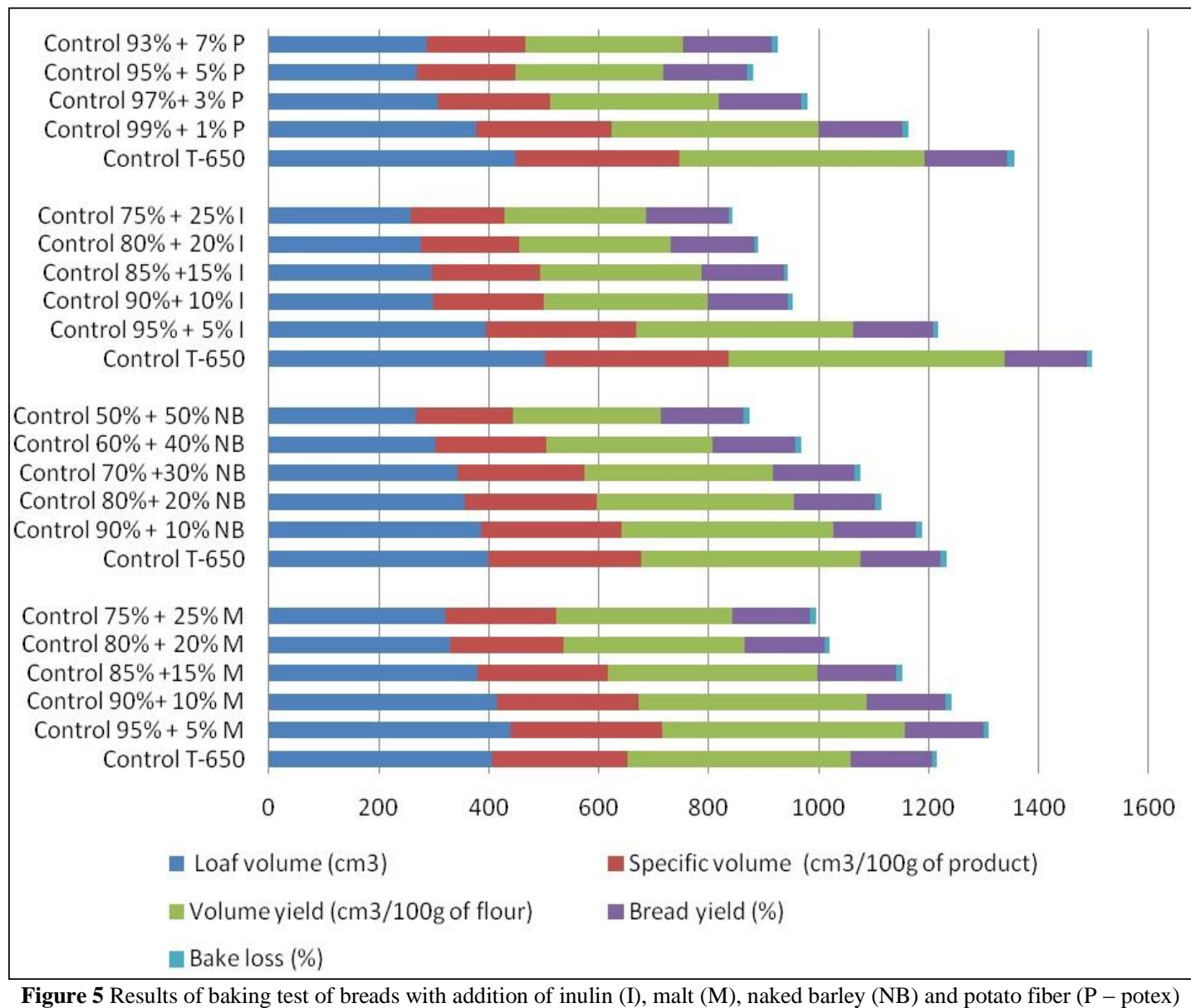

\section{Results of Sensory Analysis}

Technological parameters of individual foods are important in terms of production but should not be forgotten that all food products are intended for consumption and therefore also require acceptable organoleptic properties. The results of sensory evaluation of bread showed worsening majority of evaluations parameters in depending on the amount of inulin addition. The highest total of points gained control bread and bread with inulin addition of 5\% (86 out of 100), breads with a higher addition of inulin had sensory properties significantly worse (Fig. 6). Breads with the total number of points under 50 were assessed by a sensory panel as unsatisfactory. The highest acceptable addition of inulin which the amount significantly negative does not influenced by surface appearance, crumb appearance, smell, taste and overall acceptability, was the addition 5\%.

The highest total number of points gained bread containing $10 \%$ naked barley (91.9 points out of 100), it was surprising finding in order to gain more points compared to the control. Breads with a higher proportion of barley were evaluated worse sensory properties, decreased as follows (Fig. 6).
Addition of inulin have the biggest impact on the bread volume, texture, crust color and crumb porosity, as well as found others author (Praznik et al., 2002; Korus et al., 2006; Morris - Morris 2012).

On the basis of sensory evaluation of the loaves baked with the addition of malt was found that the highest total score obtained by the addition of malt bread with $5 \%$ (78 out of 100), it was found surprisingly to gain the more points compared to the control. Breads with a higher proportion of malt had sensory properties evaluated worse decreased as follows (Fig. 6).

The results of sensory evaluation of bread showed worsening majority of evaluations parameters in depending on the amount of Potex addition. The highest total of points gained control bread (94.28 points out of 100), breads with a higher addition of Potex had worse a sensory characteristics (Fig. 6), while also not observed striking differences than others addition. The highest acceptable addition of Potex, which significantly negative do not influenced by surface appearance, crumb appearance, smell, taste and overall acceptability, was the addition $7 \%$. 


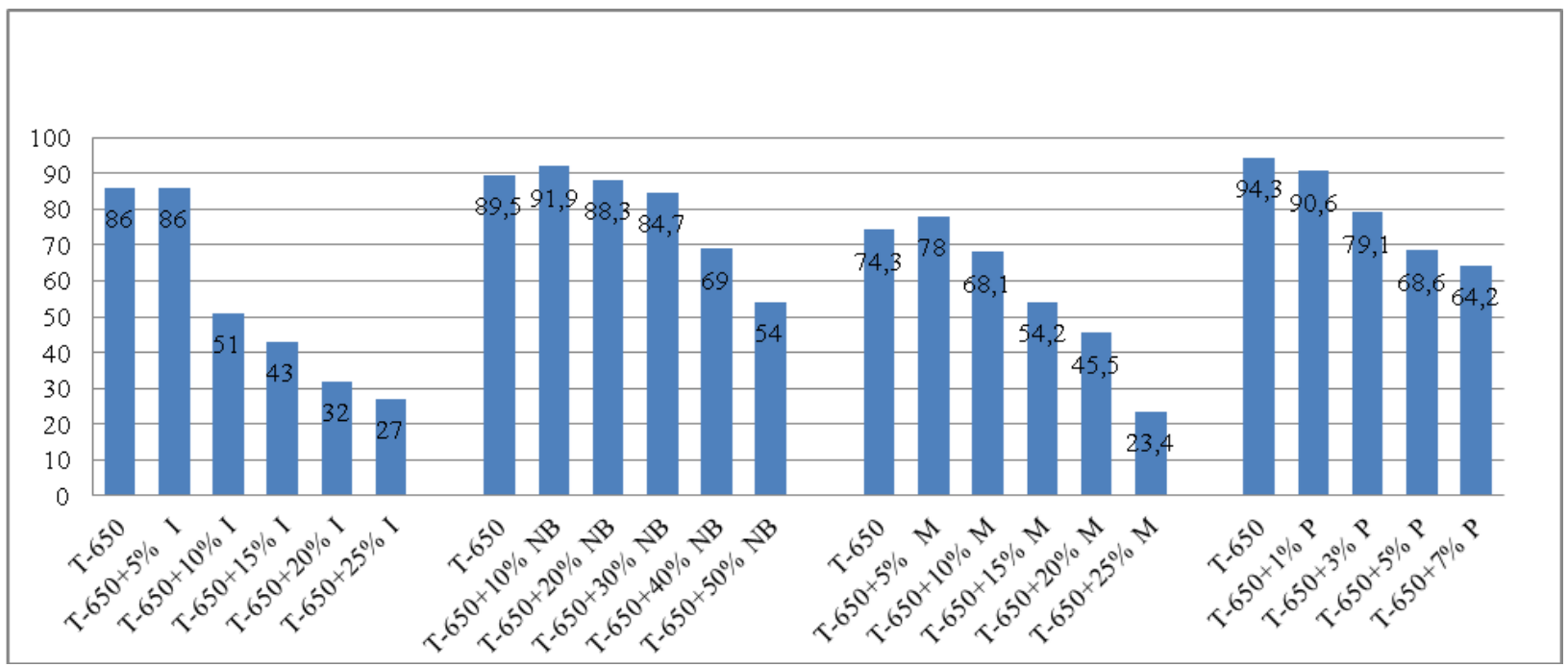

Figure 6 Sensory evaluation of breads with addition of inulin (I), malt (M), naked barley (NB) and potato fiber (P - potex)

\section{CONCLUSION}

In conclusion, breads with inulin, potato fiber, naked barley and malt substitutions were found to be nutritionally superior (have higher ash, fiber content) to $100 \%$ wheat bread. However, the scores for organoleptic attributes like taste, aroma, texture (mouth feel), except for colour were generally inferior to that of wheat bread. Therefore, the wheat bread had better overall acceptability scores than breads with inulin, potato fiber, naked barley and malt substitutions The composite breads would serve as functional food because of the high fiber content. However, further research work should be focused on the phytochemical content and how to improve the organoleptic qualities and hence acceptability of breads with inulin, potato fiber, naked barley and malt. Public enlightenment on the nutritional benefits of the fiber-supplemented functional foods would help to improve the sensory acceptability of the fiber supplemented bread. There is also the need to adjust the mixing ingredients and baking techniques in order to improve the composite bread qualities.

Acknowledgments: This work was co-funded by European Community under project no 26220220180: Building Research Centre "AgroBioTech"

\section{REFERENCES}

AACC methods 8th, E.d., 1996. Methods 08-01, 44-05A, 46-13, 54-20. St. Paul, $\mathrm{MN}$ : American Association of Cereal Chemists.

AACC-International Approved Method of Analysis 11th Ed. AACC International, St. Paul, MN, U.S.A.

ANGIOLONI, C.C. 2009. Small and large deformation viscoelastic behaviour of selected fibre blends with gelling properties.In Food Hydrocolloids, 23, 742-748. doi: 10.1016/j.foodhyd.2008.04.005.

BEHALL, K.M, SCHOLFIELD, D.J, HALLFRISCH J. 2004.Diets containing barley significantly reduce lipids in mildly hypercholesterolemic men and women. In American Journal of Clinical Nutrition, 80, 1185-93.

BRASIL, J. A. - DA SILVEIRA, K. C. - SALGADO, S. M. - SOUZA LIVERA A. V. - DE FARO, Z. P. - GUERRA, N. B. 2011. Effect of the addition of inulin on the nutritional, physical and sensory parameters of bread. In Brazilian Journal of Pharmaceutical Sciences, 47, 1, 185-191.

CAMIRE, M.E., VIOLETTE, D., DOUGHERTY, M.P., MClAuGHLIN,

M.A. 1997. Potato Peel Dietary Fiber Composition: Effects of Peeling and Extrusion Cooking Processes. In Journal of Agricultural and Food Chemistry, 45, 1404-1408. doi: 10.1021/jf9604293.

ELLEUCH, M., BEDIGIAN, D., ROISEUX, O., BESBES, S., BLECKER, C., ATTIA, H. 2011. Dietary fibre and fibre-rich by-products of food processing: Characterisation, technological functionality and commercial applications: Rev. In Food Chemistry, 124, 411-421. doi:10.1016/j.foodchem.2010.06.077

FAOWHOUNU Expert Consultation. 1994. Food Nutrients Requirements, Report of a Joint FAO/WHO/NU Expert Consultation. World Health Organization Technical Report Series 724. Geneva: WHO.

FILIPOVIC, J. - FILIPOVIC, N. - FILIPOVIC, V. 2010. The effects of commercial fibres on frozen bread dough. In Journal of the Serbian Chemical Society, 75, 2, 195-207. doi: 10.2298/JSC1002195F.

FILIPOVIC, J. - POPOV, S. - FILIPOVIC, V. 2008. The behaviour of different fibres at bread dough freezing. In Chemical Industry \& Chemical Engineering Quarterly. 14, 4, 257-259.

GILL, S. - VASANTHAN, T. - OORAIKUL, B. - ROSSNAGAL, B. 2002 Wheat breadquality is influenced by the substitution of waxy and regular barley flours in their native end cooked forms. In Journal of Cereal Science, 36, 2, 239 251

GOESAERT, K., BRIJS, W. S.,VERAVERBEKE， C. M., COURTIN, K GEBRUERS, J., DELCOUR, A. 2005. Wheat flour constituents: how they impact bread quality, and how to impact their functionality. In Trends in Food Science and Technology, 16, 12 . doi:10.1016/j.tifs.2004.02.011.

GROBELNIK MLAKAR, S., BAVEC, M., TURINEK, M., BAVEC, F. 2009 Rheological properties of dough made from grain amaranth - cereal composite flours based on wheat and spelt. In Czech Journal of Food Sci.ience, 27, 309-319. HAGER, A. S., RYAN, L. A. M., SCHWAB, C., GANZLE, M. G., O'DOHERTY, J. V., ARENDT, E.K. 2011. Influence of the soluble fibres inulin and oat B-glucan on quality ofdough and bread. European Food Research and Technology. 232

405-413. doi: org/10.1007/s00217 -010-1409-1.

ICC 107/1: 1995. Determination of the "Falling Number" according to Hagberg as a Measure of the Degree of Alpha-Amylase Activity in Grain and Flour. ICC 116/1. 1994. Determination of the sedimentation index.

ICC Standard methods of the International Association for Cereal Science and Technology. Standard No. 115/1, ICC, Vienna, Austria, 2003.

INGRAM, C. - SHAPTER, S. 2006, The Bread. Bible. Anness Publishing: London. 265 pp. ISBN 9781844763016.

ISO 5529 . 2007. Wheat - Determination of the sedimentation index - Zeleny test ISO 6658: 2005 Sensory analysis -- Methodology -- General guidance

IZYDORCZYK, M. S. - DEXTER, J. E. 2008. Barley b-glucans and arabinoxylans: Molecular structure, physicochemical properties, and uses in food products. In Food Research International, 41, 9, 850-868. doi: 10.1016/j.foodres.2008.04.001.

KAACK, K., PEDERSEN, L., LAERKE, H. N., MEYER, A.2006. New potato fibre for improvement of texture and colourof wheat bread. European Food Research Technology. 224, 199-207. doi:.org/10.1007/s00217-006-0301-5.

KAROLINI-SKARADZINSKA，Z., BIHUNIAK， P., PIOTROWSKA， E. WDOWIK, L. 2007. Properties of dough and qualitative characteristics of wheat bread with addition of inulin. In Polish Journal of Food and Nutrition Sciences. 57, 267-270.

KIM. Y.Y., JANG. K.H.,LEE. E.Y., CHO. Y., KANG. S.A., HA. W.K. CHOUE. R. 2004. The effect of chicory fructan fiber on calcium absorption and bone metabolism in Korean postmenopausal women. In Nutrition, . 7, 151-157. KORUS, J. - GRZELAK, K. - ACHREMOWICZ, K. - SABAT, R. 2006 Influence of prebioticadditions on the quality of gluten-free bread and on the content of inulin and fructooligosaccharides. In Food Science and Technology International, 12, 6, 489-495.

LATTIMER, J. M., HAUB, M. D. 2010. Effects of dietary fiber and its components on metabolic health. In Nutrients, 2, 1266-1289.

MIRSAEEDGHAZI, H., EMAM-DJOMEH, Z., MOUSAVI, S.M.A. 2008 Rheometric Measurement of Dough Rheological Characteristics and Factors Affecting It. International. In Journal of Agriculture and Biology, 10, 112-119. MEYER, D. - PETERS, B. 2009. Enhancing the nutritional value of bread with inulin. In Agro Food Industry Hi-Tech, 20, 3, 48-50.

MORRIS, C. - MORRIS, G. A. 2012. The effect of inulin and fructooligosaccharide supplementation on the textural, rheological and sensory properties of bread and their role in weightmanagement : A review. In Food Chemistry, 133, 2, 237-248. doi: 10.1016/j.foodchem.2012.01.027.

MUCHOVÁ, Z. 2001. Faktory ovplyvňujúce technologickú kvalitu pšenice a jej potravinárske využitie. 1. vyd. Nitra : SPU, 2001. 112 s. ISBN 8071379239. MUCHOVÁ, Z. 2007. Technológia spracovania cereálií. 2. vyd. Nitra : SPU, 2007. 192 s. ISBN 978-80-8069-980-2. 
O'BRIEN, C. M. - MUELLER, A. - SCANNELL, A. G. M. - ARENDT, E. K 2003. Evaluation of the effects of fat replacers on the quality of wheat bread. In Journal of Food Engineering, 56, 2-3, 265-267.

OSTMAN E.,ROSSI E., LARSSON H., BRIGHENTI F., BJORCK I. 2006. Glucose and insulin response in healthy men to barley bread with different levels of $(1 \rightarrow 3,1 \rightarrow 4)$ - $\beta$-glucans; predictions using fluidity measurements of in vitro enzyme digests. In Journal of Cereal Science, 43, 230- 235. Doi:10.1016/1.1cs.2005.11.001.

PERESSINI, D., SENSIDONI, A. 2009. Effect of soluble dietary fibre addition on rheologicaland breadmaking properties of wheat doughs. Journal of Cereal Science. 49, 190-201. doi:.org/10.1016/j.jcs.2008.09.007.

PERTEN, H. 1964. Application of the falling number method for evaluation of alpha-amylase activity. In Cereal Chemistry, 41, 127-140.

PRAZNIK, W. - CIESLIK, E. - FILIPIAK-FLORKIEWICZ, A. 2002. Soluble dietary fibers in Jerusalem artichoke powders: Composition and application in bread. In Nahrung/Food, 46, 3, 151-157.

PŘIIHODA, J. , HUMPOLÍKOVÁ, P., NOVOTNÁ, D. 2003. Základy pekárenské technologie. Praha : Pekař a cukráŕ s.r.o.. 363 s. ISBN 80-902922-1-6.

RIBOTTA, A. - LEÓN, E. - AÑÓN, M. 2003. Effect of dough freezing and frozen storage on the gelatinizarion and retrogradation of amylopectin in bread baked in a differential scanning colorimeter. In Food Research International, 36, 357-363. doi:10.1016/S0963-9969(02)00227-2.

ROUILLE, J., VALLEA, G. D., LEFEBVRE, J., SLIWINSKI, E., VLIET, T. 2005. Shear and exstressal properties of bread doughs affected by their minor components. In Journal of Cereal Science. 42, 45-57. doi:org/10.1016/j.jcs.2004.12.008.

SANGNARK, A. NOOMHORM. 2004. Chemical, physical and baking properties of dietary fiber prepared from rice straw In Lebensmittel-Wissenschaft und Technologie, 37, 697-704. DOI:10.1016/j.foodres.2003.09.007.

SERREM, C., KOCK, H., TAYLOR, J. 2011. Nutritional quality, sensory quality and consumer acceptability of sorghum and bread wheat biscuits fortified with defatted soy flour. In International Journal of Food Science and Technology, 46, 74-83. doi: 10.1111/j.1365-2621.2010.02451.x

SKENDI, A., BILIADERIS, C. G., PAPAGEORGIOU, M., IZYDORCZYK, M. S. 2010. Effects of two barley b-glucan isolates on wheat flour dough and bread

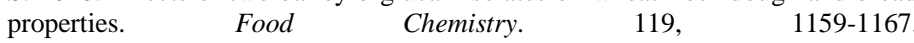
doi:org/10.1016/j.foodchem.2009.08.030.

SLAVIN, J.L 2005. Dietary fiber and body weight.In Nutrition, 21, 411-418. doi:10.1016/j.nut.2004.08.018.

SOARES R.M.D., DEFRANCISCO A., RAYAS-DUARTE P., SOLDI V. 2007. Brazilian hull-less and malting barley genotypes: I. Chemical composition and partial characterization. In Journal of Food Quality, 30, 357-371. doi: 10.1111/j.1745-4557.2007.00127.x.

SORAL-ŚMIETANA, M., WALKOWSKI, A., WRONKOWSKA, M., LEWANDOWICZ, G. 2003. Potato fibre preparation - chemical characteristics, microstructure and functional properties in baking products. Polish Journal of Food and Nutrition Sciences. 53, 119-124.

STN 461011-9. 1988. Slovak technical norm for cereals and legumes and oil seeds.

SUDHA, M. L. - BASKARAN, V. - LEELAVATHI, K. 2007a. Apple pomace as a source of dietary fibre and polyphenols and its effect on the rheological characteristics and cake making. In Food Chemistr, 104, 2, 686-692.

SUDHA, M. L. - VETRIMANI, R. - LEELAVATHI, K. 2007b. Influence of fibre from different cereals on the rheological characteristics of wheat flour dough and on biscuit quality. In Food Chemistry, 100, 4, 1365-1370.

TOPPING, D.L. 1991. Souluble fibre polysaccharides: Effects on plasma cholesterol and colonic fermentation. In Nutrition Reviews, 49, 195-203.

WANG, J. - ROSELL, C. M. - BENEDITO DE BARBER, C. 2002. Effect of the addition of different fibres on wheat dough performance and bread quality. In Food Chemistry, 79, 2, 221-26. 